\title{
Dyeing of cotton yarn with marigold (Tagetes erecta) petals: An emphasis on pre-treatments and mordants
}

\author{
Jyoti V. Vastrad*, Leela N. Walmiki and Giridhar Goudar \\ Sciences, Dharwad -580005 (Karnataka), INDIA \\ *Corresponding author. E-mail: jyotivastrad@gmail.com \\ Received: May 7, 2016; Revised received: January 24, 2017; Accepted: May 28, 2017
}

All India Coordinated Research Project on Home Science (Clothing and Textiles), University of Agricultural

\begin{abstract}
Natural dyes and eco-friendly finishing of textile fabrics is gaining popularity because of the consciousness of people in saving the ecology. Widely available resources in India have encouraged researchers in experimenting on extraction and application of dyes for textile colouration. The aim of the present experiment was to standardize a protocol for optimization of pre-treatment, mordanting and dyeing of cotton yarn with African marigold flower petals. Myrobolan, pomegranate rind and tamarind hull were utilized in different concentrations for pre-treatment. Effect of different mordants and pre-treatment concentrations on colour strength $\left(\mathrm{K} / \mathrm{S}, \mathrm{L}, \mathrm{a}^{*}\right.$ and $\left.\mathrm{b}^{*}\right)$ parameters of the cotton yarn is was studied. Optimised pre-treatment concentrations, mordants and dyeing techniques on colourfastness parameters are also presented. Myrobolan followed by pomegranate rind pre-treatment produced darker and even shades on cotton yarns. Metallic salts viz.,Stannous Chloride, Copper Sulphate and Ferrous Sulphate proved to produce shades with good to excellent colourfastness properties.
\end{abstract}

Keywords: Eco-friendly finishing, Marigold, Mordants, Natural dyeing, Pre-treatments

\section{INTRODUCTION}

Marigold is one of the widely used flowers in many of the Indian festivals, rituals and traditions. African marigold is known for their large flower sizes with very bright orange colour. Most of the flowers discarded after use and hence natural dyeing is an alternative to use this wasted biomass. Marigold flowers are rich in bio active components especially the carotenoid pigment, lutein. Natural tannin rich sources are used as pre-treatments that influence dye uptake and preferable over metallic salts. African marigold (Tagetes erecta) is a hardy annual plant about $90 \mathrm{~cm}$ tall, erect and branched. Florets are either 2 lipped or quilled. Flower colour varies from lemon yellow to golden yellow and orange. It is grown as a cut flower and a garden flower, in addition to being grown for its medicinal values. Marigold flowers, which are yellow to orange red in colour, are a rich source of lutein, a carotenoid pigment. Nowadays, Lutein is becoming an increasingly popular active ingredient used in the Food Industry and Textile coloration. This pigment has acquired greater significance because of its excellent colour value. In 1972, Quackenbush and Miller separated lutein and 16 common lutein fatty acid esters which, on the whole, represented over $95 \%$ of the pigments identified in the petals of the marigold.

Although marigold flower extract has been used in veterinary feeds, the potential use of marigold as a natural textile colorant has not been exploited to its full extent. This is due to the lack of information on its safety, stability, and compatibility in textile coloration (Jothi, 2008). Natural dyes are mostly non-substantive and must be applied on textiles by the help of mordants, usually a metallic salt, having an affinity for both the colouring matter and the fibre. Marigold is one of the plants of medicinal value with wide applications in ayurvedic formulations for the treatment of skin problems, inflammation of the skin, either due to infection or any physical damage. Phytochemical screening of the Tagetes erecta have proved to contain flavonoid, alkaloid, quinones, Phenols, triterpenoid and coumarins bioactive compounds which are of medicinal value and have a definite physiological action on the human body (Devika and Koilpillai, 2015) reported potential benefits include Age-Related Macular Degeneration (AMD) (Landrum and Bone, 2001), enhanced immune function, and protection against oxidant induced cell damage (Olmedilla et al., 2001).

Natural dyes are known for their use in colouring of food substrate, leather as well as natural protein fibres like wool, silk and cotton as major areas of application since pre-historic times. The use of non-allergic, nontoxic and eco-friendly natural dyes on textiles has become a matter of significant importance due to the increased environmental awareness in order to avoid some hazardous synthetic dyes (Ashis and Priti, 2009). Recent resurgence in research and development on natural dye production and application is observed due to increasing popularity of more natural lifestyle based 
on naturally sustainable goods (Jha et.al., 2015). At present there is an excessive use of synthetic dyes, the production and application of these dyes release vast amounts of waste and unfixed colorants, causing serious health hazards and disturbing the ecological balance of nature (Ghorpade et al., 2000; Jyoti, 2008; Adeel et al., 2009; Singh and Purohit, 2012). A number of commercial dyers and small textile export houses have started looking at the possibilities of using natural dyes for regular basis dyeing and printing of textiles to overcome environmental pollution caused by the synthetic dyes (Glover and Pierce, 1993). Mordanting can be achieved by either pre-mordanting, simultaneously mordanting and post-mordanting. Different types and selective mordants or their combination can be applied on the textile fabrics to obtain varying colour/shade, to increase the dye uptake and to improve the colour fastness property of any natural dye, several researchers have reported on this study (Paliwal, 2001; Paul et al., 2002).

Thousands of flowers used are thrown into the pits on drying. It would be worthwhile if the waste that is rich in phenolics can be used for value addition. Textile colouration is one of the technologies that is averting towards eco-friendly procedures. Clothing being one of the basic necessities then is now considered as symbol of status that defines the socio-economic status of an individual. Fashion and style are the next concerns among people with a flare for self grooming. Growing consciousness of the consumers to save mother earth is propagating the use of eco-friendly biodegradable products. For successful commercial use of natural dyes, the appropriate and standardized dyeing techniques need to be adopted without scarifying required quality of dyed textile materials (Ashis and Priti, 2009). Owing into the advantages of natural dyes of not only being eco-friendly but also antimicrobial, the present study was undertaken to standardize a protocol for dyeing of cotton yarn with marigold dye extract and to know the effect of various pre treatments and mordants on the colour parameters of marigold dyed cotton yarns.

\section{MATERIALS AND METHODS}

Sourc of raw material: Fully bloomed marigold flowers of Orange double variety freshly harvested were procured from the experimental plots of the Department of Horticulture, University of Agricultural Sciences, Dharwad. Myrobolan, pomegranate rind powder and tamarind hull powder were sourced from one of the Ayurvedic Bhishaks at Belgaum.Grey cotton yarn of $2 / 60$ s was procured from a local yarn merchant.

Chemicals: Metallic salts viz. Potash Alum $\left(\mathrm{AlK}\left(\mathrm{SO}_{4}\right)\right.$ $\left.{ }_{2} .12 \mathrm{H}_{2} \mathrm{O}\right)$, Copper Sulphate $\left(\mathrm{CuSO}_{4}\right)$, Aluminium Acetate $\left(\mathrm{Al}\left(\mathrm{C}_{2} \mathrm{H}_{2} \mathrm{O}_{2}\right)_{3}\right)$, Lead Acetate $\left(\left(\mathrm{CH}_{3} . \mathrm{COO}\right)\right.$ $\left.{ }_{2} \mathrm{~Pb} .3 \mathrm{H}_{2} \mathrm{O}\right)$, Ferrous Sulphate $\left(\mathrm{FeSO}_{4} .7 \mathrm{H}_{2} \mathrm{O}\right)$, Stannous Chloride $\left(\mathrm{SnCl}_{2} \cdot 2 \mathrm{H}_{2} \mathrm{O}\right)$ and Zinc Chloride $\left(\mathrm{ZnCl}_{2}\right)$ were procured from Merck, Mumbai were used as mordants.

Processing and preparations: Yarn of 2/60s was desized by boiling in 2gpl detergent for 30 minutes with Material to Liquor Ratio of 1:30. The desized yarn was rinsed thoroughly and dried.

Marigold petals were removed from the calyx without pulling out the seeds, dried in a hot air oven at $50^{\circ} \mathrm{C} \pm 2^{\circ} \mathrm{C}$. Dried petals were powdered in a laboratory blender, packed and refrigerated.

\section{Optimization of pre-treatment type and concentration: \\ Pre treatment agent : Myrobolan, pomegranate rind, tamarind hull \\ Concentration $\quad: 1 \%, 2 \%$ and $3 \%$ each}

Material to Liquor Ratio MLR : 1:10

Calculated amounts of the pre-treatment agents were soaked overnight with the Material-to-liquor ratio of 1:30. Scoured cotton yarns pre-soaked in water containing a surfactant like Turkey Red Oil were dipped in the pre-treatment agents for three hours. The yarn were squeezed and dried in sunlight. The pre-treated yarn was later dyed in 1 per cent concentration of marigold dye with an MLR of 1:20 for 30 minutes at boiling temperature. The dyed samples were squeezed and line dried in shade for oxidation reactions if any to occur and later rinsed in plain water twice and dried completely in shade.

The pre-treated and dyed samples were assessed for Colour Strength $(\mathrm{K} / \mathrm{S})$ values at $400 \mathrm{~nm}$ using a Spectrophotometer with Premier colour scan software. K/S value denotes the fabric color strength. This method also involves Kulbelka- Munk K/S equation, which indicates that the production of reflected light involves absorption and scattering. Based on the \% reflectance (R), K/S can be calculated by the following formula:

$\mathrm{K} / \mathrm{S}=(1-\mathrm{R}) 2 / 2 \mathrm{R}$ .eq. 1

where $\mathrm{K}$ is the absorption coefficient and $\mathrm{S}$ is the Scattering coefficient. (Jha et al., 2015) Samples recording the highest $\mathrm{K} / \mathrm{S}$ values and the concentration were selected for optimization of Dye concentration.

Optimization of dye and mordant concentration: Cotton yarn pre-treated with selected pre-treatment type and concentration were dyed with various combinations of mordant and dye concentrations with the recipe given below:

\section{Mordanting}

Mordant : Potash Alum

Concentration $: 0.5,1,1.5$ and $2 \%$ (owf)

MLR $: 1: 10$

Treatment time $: 20 \mathrm{~min}+10 \mathrm{~min}$

Dyeing

Concentration $\quad: 0.5 .1 .0,1.5,2.0$ and $2.5 \%$

MLR : :1:30

Dyeing time $: 20+10$ minutes

Temperature : Boiling

Samples were dipped in luke warm mordant solution 
for 20 minutes, squeezed and put into the boiling dye liquor for 20 minutes. As an intermediate treatment, the cotton yarn was re-dipped in the mordant solution for 10 minutes and later was again dyed for 10 minutes. Dyed yarn was allowed to partially dry under shade and later rinsed and dried. The optimization of mordant and dye concentration was done based on the Colour Strength $(\mathrm{K} / \mathrm{S})$ values.

Optimization of pre-treatment and mordant combinations: An effort was made to study the effect of different pre treatment concentrations and mordants on $\mathrm{K} / \mathrm{S}$ of the marigold dyed fibres by keeping the mordant concentration constant at 1 per cent. Samples pre-treated with various concentrations (1,2 and 3\%) of myrobolan, pomegranate rind and tamarind hull were dyed in 1 per cent each mordant and dye concentrations. Optimization of the pre treatment and mordant concentrations were done referring to the $\mathrm{K} / \mathrm{S}$ values measured at $400 \mathrm{~nm}$.In a similar study, which reported the use of Potash Alum in the mordanting of cotton fabrics dyed with natural dyes Wanyama et al (2011).

Quality assessment

Colour strength: Colour strength parameters viz., Colour Strength (K/S), Lightness/Darkness values (L), Redness/greenness values $\left(\mathrm{a}^{*}\right)$ and yellowness/ blueness values $\left(b^{*}\right)$ were assessed using Spectrophotometer (SS5100A) with Premier Colour scan software $($ Colorlab +$)$. The Colour Strength for the integrated wavelength option available in the software was recorded. However the instrument measures reflectance and transmission of the given samples at $360 \mathrm{~nm}$ to $740 \mathrm{~nm}$. Differences in colour parameters $(\delta \mathrm{E}, \delta \mathrm{L}, \delta \mathrm{a}$, $\delta b)$ were also recorded. The readings of the instrument and the principle of the equipment is in accordance with CIE L*a*b* standards.

Colourfastness: Colourfastness studies to various agents viz., Sunlight, washing, wet and dry rubbing and acid and alkaline perspiration were tested using standard test methods (IS: 971-1983 for Colour fastness to perspiration; IS: 686-1985 for Light; IS: 687-1979 for Wash; IS: 766-1988 for Rubbing). Ratings for sunlight fastness were assigned as per the blue wool standards and those for washing, rubbing and perspiration as per grey scale.

\section{RESULTS AND DISCUSSION}

Characterization and quantificationis one of the preliminary requirements of optimization process. Optimi-

Table 1. Colour Strength (K/S) values of the marigold dyed cotton yarn with different pre-treatment types and concentrations.

\begin{tabular}{llll}
\hline \multirow{2}{*}{ Pre-treatment type } & \multicolumn{3}{l}{ Concentration } \\
\cline { 2 - 4 } & $\mathbf{1 \%}$ & $\mathbf{2 \%}$ & $\mathbf{3 \%}$ \\
\hline Myrobolan & 31.931 & 43.598 & 47.427 \\
Pomegranate rind & 6.825 & 8.360 & 9.942 \\
Tamarind hull & 34.892 & 36.580 & 43.189 \\
\hline
\end{tabular}

zation is standardization of the source processing, auxiliaries, pre-treatments, mordants, concentrations, treatment time, temperature, $\mathrm{pH}$, etc. (Vastrad et al., 2016). Optimization of pre-treatment type and concentration: Irrespective of the pre-treatment type an increase in the K/S was observed with increase in the concentrations. Myrobolan 2 per cent was selected for further studies. Myrobolan (Terminalia chebula) also known as haritaki in Sanskrit and hindi, belongs to the family Combretaceae. The tree is found in the western ghat forests of Karnataka. (Vastrad et.al., 2016) The fruit contains several phytoconstituents like tannins, flavonoids, sterols, amino acids, fructose, resin, etc. It is fairly rich (32\%) in tannins that is largely dependent on its geographic location. (Kumar et.al., 2006). On the other hand rind of pomegranate also known for its phenolics is said to contain tannins about 19 per cent with pelletierine (Tiwari et al., 2010).

Optimization of mordant (PA) and dye concentrations: It was observed that an increase in the dye concentration increased the K/S value. However, the reading at 2.00 and 2.50 per cent concentration of the dye was found to be on par with each other. Similarly an increase in the mordant (PA) concentration from 0.50 to 1.00 per cent brought in significant increase in the $\mathrm{K} / \mathrm{S}$ values. However the difference between the K/S of 1.0, 1.5 and 2.00 percent mordant concentration was non-significant. In Chemical terms, mordants are defined as polyvalent metallic compounds which can develop co-ordinate and covalent complexes with dyes and fibres (Baker, 1958). However, typically metallic atom forms covalent bond with hydroxyl/carboxyl oxygen on the dye/fibre and a co-ordinate bond with adjacent long pair of electrons on double bonded oxygen. Mordants can chelate several dye molecules together creating a larger complex and provide link between the dye and fibre. They also assist fibre to retain colour, increasing depth of shade, fastness to wet and mechanical treatments (Gordon and Gregory, 1983). Based on the readings in the Table 2, mordant concentration of 1 per cent and dye concentration of 2 per cent was selected for bulk dyeing.

Optimization of pre-treatment and mordant combinations: It is clear from the table 3 that the $\mathrm{K} / \mathrm{S}$ values were higher with the samples pre treated with myrobolan and mordanted using different metallic salts. With Aluminium Acetate, Ferrous Sulphate, Lead Acetate

Table 2. K/S of the cotton yarn samples dyed with different concentrations mordant (PA) and Dye.

\begin{tabular}{lllll}
\hline $\begin{array}{l}\text { Dye Concen- } \\
\text { tration (\%) }\end{array}$ & \multicolumn{4}{l}{ Mordant (PA) concentrations (\% owf) } \\
\cline { 2 - 5 } & $\mathbf{0 . 5 0}$ & $\mathbf{1 . 0 0}$ & $\mathbf{1 . 5 0}$ & $\mathbf{2 . 0 0}$ \\
\hline Control & 22.418 & 44.343 & 43.717 & 45.391 \\
0.50 & 25.799 & 31.262 & 30.662 & 32.967 \\
1.00 & 37.139 & 77.042 & 79.021 & 81.564 \\
1.50 & 70.171 & 138.788 & 141.002 & 143.201 \\
2.00 & 104.662 & 282.240 & 285.128 & 287.026 \\
2.50 & 113.762 & 289.410 & 291.180 & 293.526 \\
\hline
\end{tabular}


Jyoti V. Vastrad et al. / J. Appl. \& Nat. Sci. 9 (2): 1282 - 1286 (2017)

Table 3. K/S values of the cotton yarn samples pre-treated with different agents and mordants

\begin{tabular}{|c|c|c|c|c|c|c|c|c|c|c|c|}
\hline \multirow{2}{*}{\multicolumn{2}{|c|}{ Mordant }} & \multicolumn{4}{|c|}{ Myrobolan } & \multicolumn{3}{|c|}{ Pomegranate rind } & \multicolumn{3}{|c|}{ Tamarind hull } \\
\hline & & $1 \%$ & \multicolumn{2}{|c|}{$2 \%$} & $3 \%$ & $1 \%$ & $2 \%$ & $3 \%$ & $1 \%$ & $2 \%$ & $3 \%$ \\
\hline \multicolumn{2}{|c|}{ Aluminium Acetate } & 47.498 & \multicolumn{2}{|c|}{63.790} & 64.718 & 9.581 & 16.376 & 22.480 & 29.29 & 48.744 & 40.696 \\
\hline \multicolumn{2}{|c|}{ Copper Sulphate } & 79.197 & \multicolumn{2}{|c|}{371.74} & 212.13 & 88.63 & 77.566 & 110.339 & 24.356 & 53.361 & 57.574 \\
\hline \multicolumn{2}{|c|}{ Ferrous Sulphate } & 184.739 & \multicolumn{2}{|c|}{233.976} & 309.49 & 271.628 & 241.190 & 182.266 & 55.001 & 87.347 & 163.031 \\
\hline \multicolumn{2}{|c|}{ Lead Acetate } & 53.268 & \multicolumn{2}{|c|}{97.611} & 257.028 & 92.626 & 90.004 & 103.134 & 26.949 & 51.142 & 61.226 \\
\hline \multicolumn{2}{|c|}{ Potash Alum } & 99.399 & \multicolumn{2}{|c|}{181.261} & 174.472 & 163.486 & 131.873 & 123.540 & 49.083 & 100.977 & 110.509 \\
\hline \multicolumn{2}{|c|}{ Stannous Chloride } & 94.306 & \multicolumn{2}{|c|}{450.413} & 759.488 & 353.697 & 213.134 & 262.625 & 68.179 & 169.659 & 129.546 \\
\hline \multicolumn{2}{|c|}{ S. N. Sample } & \multicolumn{2}{|c|}{$\begin{array}{l}\text { Myrobo- } \\
\text { lan conc. }\end{array}$} & \multicolumn{2}{|c|}{ Particulars } & $\mathbf{K} / \mathbf{S}$ & $\mathbf{L}$ & $\mathbf{A}$ & b & $\mathbf{c}$ & $\mathbf{H}$ \\
\hline 1 & & \multicolumn{2}{|c|}{-} & \multicolumn{2}{|c|}{ Control } & 81.403 & 50.097 & 5.201 & 34.813 & 35.199 & 81.470 \\
\hline 2 & & \multicolumn{2}{|c|}{$3 \%$} & \multicolumn{2}{|c|}{$\begin{array}{l}\text { Ferrous } \\
\text { Sulphate }\end{array}$} & $\begin{array}{l}680.991 \\
(48.603)\end{array}$ & $\begin{array}{c}38.400 \\
(-12.280)\end{array}$ & $\begin{array}{c}-1.917 \\
(-7.118)\end{array}$ & $\begin{array}{c}8.914 \\
(-25.899)\end{array}$ & $\begin{array}{c}9.118 \\
(-26.082)\end{array}$ & $\begin{array}{l}102.168 \\
(6.417)\end{array}$ \\
\hline 3 & & \multicolumn{2}{|c|}{$2 \%$} & \multicolumn{2}{|c|}{$\begin{array}{c}\text { Copper } \\
\text { Sulphate }\end{array}$} & $\begin{array}{l}402.158 \\
(20.532)\end{array}$ & $\begin{array}{l}53.315 \\
(2.635)\end{array}$ & $\begin{array}{c}6.874 \\
(1.673)\end{array}$ & $\begin{array}{l}42.455 \\
(7.642)\end{array}$ & $\begin{array}{l}43.008 \\
(7.809)\end{array}$ & $\begin{array}{l}80.770 \\
(0.476)\end{array}$ \\
\hline \multicolumn{2}{|l|}{4} & \multicolumn{2}{|c|}{$3 \%$} & \multicolumn{2}{|c|}{$\begin{array}{l}\text { Stannous } \\
\text { Chloride }\end{array}$} & $\begin{array}{l}736.266 \\
(55.932)\end{array}$ & $\begin{array}{c}75.771 \\
(25.091)\end{array}$ & $\begin{array}{c}16.379 \\
(11.178)\end{array}$ & $\begin{array}{c}83.269 \\
(48.456)\end{array}$ & $\begin{array}{c}84.865 \\
(49.665)\end{array}$ & $\begin{array}{c}78.840 \\
(-2.509)\end{array}$ \\
\hline 5 & & & & & $\begin{array}{l}\text { Ace- } \\
\text { ate }\end{array}$ & $\begin{array}{l}283.393 \\
(14.866)\end{array}$ & $\begin{array}{l}54.170 \\
(3.490)\end{array}$ & $\begin{array}{c}5.019 \\
(-0.182)\end{array}$ & $\begin{array}{l}43.500 \\
(8.687)\end{array}$ & $\begin{array}{l}43.789 \\
(8.589)\end{array}$ & $\begin{array}{l}83.385 \\
(1.312)\end{array}$ \\
\hline 6 & & & & $\begin{array}{r}\text { Alu } \\
\text { A }\end{array}$ & $\begin{array}{l}\text { ninium } \\
\text { etate }\end{array}$ & $\begin{array}{l}47.752 \\
(8.504)\end{array}$ & $\begin{array}{l}51.097 \\
(0.417)\end{array}$ & $\begin{array}{c}5.096 \\
(-0.105)\end{array}$ & $\begin{array}{l}36.632 \\
(1.819)\end{array}$ & $\begin{array}{l}36.985 \\
(1.785)\end{array}$ & $\begin{array}{l}82.047 \\
(0.364)\end{array}$ \\
\hline 7 & & & & & $\begin{array}{l}\text { tash } \\
\text { lum }\end{array}$ & $\begin{array}{l}270.980 \\
(24.019)\end{array}$ & $\begin{array}{c}66.965 \\
(16.285)\end{array}$ & $\begin{array}{c}4.910 \\
(-0.291)\end{array}$ & $\begin{array}{c}61.788 \\
(26.975)\end{array}$ & $\begin{array}{c}61.983 \\
(26.783)\end{array}$ & $\begin{array}{l}85.422 \\
(3.222)\end{array}$ \\
\hline
\end{tabular}

(Figure in parenthesis indicate the $\Delta \mathrm{E}, \Delta \mathrm{L}, \Delta \mathrm{a}$ and $\Delta \mathrm{b}$ respectively), $\Delta \mathrm{E}=$ colour difference, $\Delta \mathrm{L}=$ Lightness/Darkness, $\Delta \mathrm{a}=$ Redness/Greenness, $\Delta \mathrm{b}=$ Yellowness/Blueness, $\Delta \mathrm{c}=$ Chroma.

Table 5. Colour fastness of cotton yarn dyed with marigold.

\begin{tabular}{|c|c|c|c|c|c|c|c|c|c|c|c|c|}
\hline \multirow{3}{*}{ Mordant } & \multirow{3}{*}{$\begin{array}{c}\text { Light } \\
\text { fastness }\end{array}$} & \multicolumn{3}{|c|}{ Wash fastness } & \multicolumn{2}{|c|}{ Rubbing (SC) } & \multicolumn{6}{|c|}{ Perspiration } \\
\hline & & \multirow{2}{*}{$\mathrm{CC}$} & \multirow{2}{*}{ SC } & \multirow{2}{*}{ SW } & \multirow{2}{*}{ Dry } & \multirow{2}{*}{ Wet } & \multicolumn{3}{|c|}{ Acid } & \multicolumn{3}{|c|}{ Alkali } \\
\hline & & & & & & & $\mathrm{CC}$ & SC & SW & $\mathrm{CC}$ & SC & SW \\
\hline Ferrous Sulphate & 4 & $4-5$ & $4-5$ & $4-5$ & 4 & 5 & $4-5$ & $3-4$ & $3-4$ & $4-5$ & 5 & 5 \\
\hline Copper Sulphate & $4-5$ & $4-5$ & 5 & 5 & $4-5$ & $4-5$ & $4-5$ & $3-4$ & 3 & 4 & $4-5$ & 5 \\
\hline Stannous Chloride & 5 & 5 & 5 & $4-5$ & $4-5$ & 4 & 5 & 5 & 5 & 5 & 5 & 5 \\
\hline Lead Acetate & 4 & 4 & 4 & $4-5$ & 4 & $3-4$ & 4 & $3-4$ & $3-4$ & 4 & 4 & 4 \\
\hline Aluminium Acetate & 3 & 3 & 3 & $3-4$ & 3 & $3-4$ & 3 & 3 & 3 & $3-4$ & $3-4$ & $3-4$ \\
\hline Potash Alum & $3-4$ & $3-4$ & $3-4$ & $3-4$ & 4 & 4 & $3-4$ & 4 & 4 & 4 & 4 & 4 \\
\hline
\end{tabular}

CC- Change in color, SC- Stain on cotton, SW- Stain on wool

and Stannous Chloride mordants the $\mathrm{K} / \mathrm{S}$ was maximum at 3 per cent myrobolan concentration. Whereas for Copper sulphate and Potash Alum mordants the K/ $\mathrm{S}$ was maximum at 2 per cent myrobolan concentration.

Colour assessment of the samples dyed using optimized methods: Cotton yarns pre treated with 2 per cent myrobolan were mordanted with CS and PA; Yarn pre-treated with 3 per cent myrobolan were mordanted with AA, FS, LA and SC. Dyeing was carried out with 2 per cent concentration with redipping technique for even and efficient dyeing. Samples exhibited better Colour Strength values over control. Ferrous Sulphate mordant produced the darkest shade indicat- ed by the L value (38.400) whereas lightest colour was obtained by Stannous Chloride (75.771) with the K/S of 736.266. All the samples were towards the yellower shade as indicated by the $b^{*}$ values but samples mordanted with Ferrous Sulphate were towards the greener tinge. The coordination of the mordants with the pretreatments and the dye molecules may propagate formation of complexes to facilitate better dye uptake with enhancement in the colour.

Colourfastness of dyed cotton samples: The ultimate performance expected of dyes and pigments was their fastness to various agents. Sustainability of the dye/ pigment to sunlight is of utmost importance. However, the colourfastness test authenticated the procedures 
followed for dyeing especially with the natural resources. Mordants proved to have affinity for the dye and the fibre, that aided in forming insoluble complexes within the fibre imparting good colourfastness performance to the fabric. The FS, CS, SC, and LA mordanted samples dyed with marigold dye exhibited fair to good colourfastness properties. This is due to the formation of a complex with transition metal (mordant CS, FS) which protects the chromophore from photolytic degradation and the photons sorbed by the chromophoric group dissipate their energy by resonating within the six member ring thus formed and hence protecting the dye (Jothi, 2008). Wash fastness is influenced by the rate of diffusion of dye and the state of the dye molecule inside the fibre. Cotton yarn mordanted with FS and SC exhibited very good to excellent wash, rubbing and perspiration fastness. The same can further be experimented for the biochemical composition through analytical techniques. Different constituents have different degrees of solubility in different types of solvents. The mode of action of plants producing dyeing effects on selected textile material can be better investigated if the active ingredients are identified and characterized (Vastrad and Goudar, 2016).

\section{Conclusion}

The present work indicated that 3\% myrobolan pretreatment imparted darker hues, even shades and good to excellent colour fastness compared to $1 \%$ and $2 \%$ myrobolan followed by the pomegranate rind and tamarind hull powder. Myrobolan rich in tannins are proven to improve the dye uptake and dye performance. Various shades were obtained using different pretreatments and mordanting. Mordant concentration of $1 \%$ for Stannous Chloride, Copper Sulphate and Ferrous Sulphate and dye concentration of $2 \%$ were optimized for bulk dyeing. There is a need to commercialize natural dye not only to protect the ancient and traditional folklore but also to save and protect the ecology.

\section{ACKNOWLEDGEMENTS}

The authors would like to thank Department of Biotechnology (DBT), New Delhi, India for the financial support for undertaking the research work.

\section{REFERENCES}

Adeel, S., Ali, S., Bhatti, I.A. and Zsila, F. (2009). Dyeing of cotton fabric using pomegranate (Punica granatum) aqueous extract. Asian Journal of Chemistry. 21(5): 3493-3499

Ashis,K.S. and Priti, A. (2009). Application of natural dyes on textiles. Indian Journal of Fibre and Textile Research. 34: 384-399

Baker, J. R. (1958). Principles of biological microtechnique:
A study of fixation and dyeing, New York, NY: John Wiley and Sons, Inc.

Devika R. and Koilpillai J. (2015). Phytochemical screening studies of bioactive compounds of Tagetes erecta. Int $J$ Pharm Bio Sci., 3(4): (B) 596- 602

Ghorpade, B., Darvekar, M. and Vankar, P.S. (2000). Ecofriendly cotton dyeing with Sappan wood dye using ultrasound energy. Journal of Colourage. 27-30.

Glover, B. and Pierce, J.H. (1993). Are natural colorants good for your health? Journal of the Society of Dyers and Colourists. 109(1): 5-7

Gordon, P. F. and Gregory, P. (1983). Organic chemistry in colour, New York, NY: Springer Verlag

Jha C. K., Kumar R., Kumar V.S. and Devi R.V. (2015). Extraction of natural dye from marigold flower (Tagetes erecta 1.) and dyeing of fabric and yarns: A focus on colorimetric analysis and fastness properties. Der Pharmacia Lettre, 7 (1):185-195

Jothi, D. (2008). Extraction of natural dyes from African marigold flower (Tagetes erecta) for textile coloration.Autex Research Journal. 8(2): 49-53

Kumar, S. R., Saravanan, S., Manikandan, S., Jayaparthasarathy, N. and Sheela, D. R. (2006). Hypolipidemic effect of Triphala in experimentally induced hypercholesteremic rats. Yakugaku Zasshi, (127): 2385-388.

Landrum, J.T. and Bone, R.A. (2001). Lutein, zeaxanthin, and the macular pigment. Arch. Biochem. and Biophy., 385: $28-40$.

Olmedilla, B., Granado, F., Blanco, I., Vaquero, M. and Cajigal, C. (2001). Lutein in patients with cataracts andage related macular degenerations: A long term supplementation study. J. Sci. Food Agr. 81:904-909

Paliwal, J. (2001). Effect of mordants on henna, dyed cotton and silk fabrics.Textile Magazine, 42(11): 79-81.

Paul, S., Sharma, A. and Grover, E. (2002). Optimization of dyeing conditions for dyeing of Cotton and wool with Hamelia leaves. Asian Textile Journal, 11(11): 65-69

Singh, S.V. and Purohit, M.C. (2012). Applications of eco -friendly natural dye on wool fibers using combination of natural and chemical mordants. Universal Journal of Environmental Research and Technology, 2(2): 48-55

Tiwari, H.S., Singh, P., Mishra, P.K. and Srivastav, P., (2010). Evolution of various techniques for extraction of natural colourant from pomegranate rind- Ultra sound and enzyme assisted extraction. Indian Journal of fiber and Textile research. 35 (8):272-276

Vastrad J.V., Goudar G., Walmiki, L., Mariyappannavar, S. and Mahale, G. (2016). Empowerment of Women through Dyeing technology- Inspirations from nature (Research bulletin)., University of Agricultural Sciences, Dharwad

Vastrad J. V. and Goudar, G. (2016). Development of chromatographic profiles by HPTLC and characterization of phenolics in the leaf extracts of Tectona grandis. Research Journal of Chemistry and Environment, 20(2):1-8

Wanyama, P.A.G., Kiremire, B.T. and Muyumu, J.S. (2011). Indigenous plants in Uganda as potential sources of textile dyes. African Journal of Plant Research, 5(1):28 $-39$ 